OPEN ACCESS

Edited by:

Lingqian Wu,

Central South University, China

Reviewed by:

Baoheng Gui,

The Second Affiliated Hospital of Guangxi Medical University, China

Yuan Gao,

Shandong University, China R. Douglas Wilson,

University of Calgary, Canada

${ }^{*}$ Correspondence:

Shanling Liu sunny630@126.com

tORCID:

Cechuan Deng orcid.org/0000-0002-8511-7990

Shanling Liu

orcid.org/0000-0001-8788-7991

Specialty section:

This article was submitted to Genetics of Common and Rare

Diseases,

a section of the journal

Frontiers in Pediatrics

Received: 10 November 2021 Accepted: 03 January 2022

Published: 27 January 2022

Citation:

Deng C and Liu S (2022) Factors

Affecting the Fetal Fraction in Noninvasive Prenatal Screening: A Review. Front. Pediatr. 10:812781. doi: 10.3389/fped.2022.812781

\section{Factors Affecting the Fetal Fraction in Noninvasive Prenatal Screening: A Review}

\author{
Cechuan Deng ${ }^{1,2+}$ and Shanling Liu ${ }^{1,2 * \dagger}$ \\ ${ }^{1}$ Prenatal Diagnostic Center, Department of Medical Genetics, West China Second University Hospital, Sichuan University, \\ Chengdu, China, ${ }^{2}$ Key Laboratory of Birth Defects and Related Diseases of Women and Children, Ministry of Education, \\ Sichuan University, Chengdu, China
}

A paradigm shift in noninvasive prenatal screening has been made with the discovery of cell-free fetal DNA in maternal plasma. Noninvasive prenatal screening is primarily used to screen for fetal aneuploidies, and has been used globally. Fetal fraction, an important parameter in the analysis of noninvasive prenatal screening results, is the proportion of fetal cell-free DNA present in the total maternal plasma cell-free DNA. It combines biological factors and bioinformatics algorithms to interpret noninvasive prenatal screening results and is an integral part of quality control. Maternal and fetal factors may influence fetal fraction. To date, there is no broad consensus on the factors that affect fetal fraction. There are many different approaches to evaluate this parameter, each with its advantages and disadvantages. Different fetal fraction calculation methods may be used in different testing platforms or laboratories. This review includes numerous publications that focused on the understanding of the significance, influencing factors, and interpretation of fetal fraction to provide a deeper understanding of this parameter.

\footnotetext{
Keywords: noninvasive prenatal screening, cell-free fetal DNA, fetal fraction, molecular genetics, genetic counseling
}

\section{INTRODUCTION}

Circulating cell-free DNA has been proven to be useful for noninvasive oncological examinations and general medical examinations by numerous studies. Cell-free fetal DNA (cffDNA), originating from placental tissue and found in maternal plasma, was first reported in (1) and was initially used for fetal sex determination (2). With the advent of next-generation sequencing, two studies published in 2008 showed that cffDNA can be used to screen for common autosomal aneuploidies in fetuses $(3,4)$. Subsequently, cffDNA was included in trisomy 21 screening in $(5)$. Various tests that use cffDNA to screen for fetal aneuploidies have been developed since then and are collectively called noninvasive prenatal screening (NIPS) (6).

The circulating cell-free DNA found in maternal plasma includes DNA of both maternal and fetal origins. Maternal circulating cell-free DNA originates from all maternal organs, including solid tumors, and mainly from the hematopoietic system. cffDNA is primarily derived from placental trophoblast cells and represents fetal DNA (placental DNA). Fetal fraction (FF) is the ratio of cffDNA to all circulating cell-free DNA in the maternal plasma (Figure 1). At 10-20 weeks of gestation (the most common time for NIPS), FF is $\sim 10-15 \%(5,7)$. During NIPS, maternal and fetal cell-free DNA is not separated, so it is imperative to understand FF to accurately interpret NIPS results. Substantial research on the FF has been performed to date, but it is relatively scattered. 


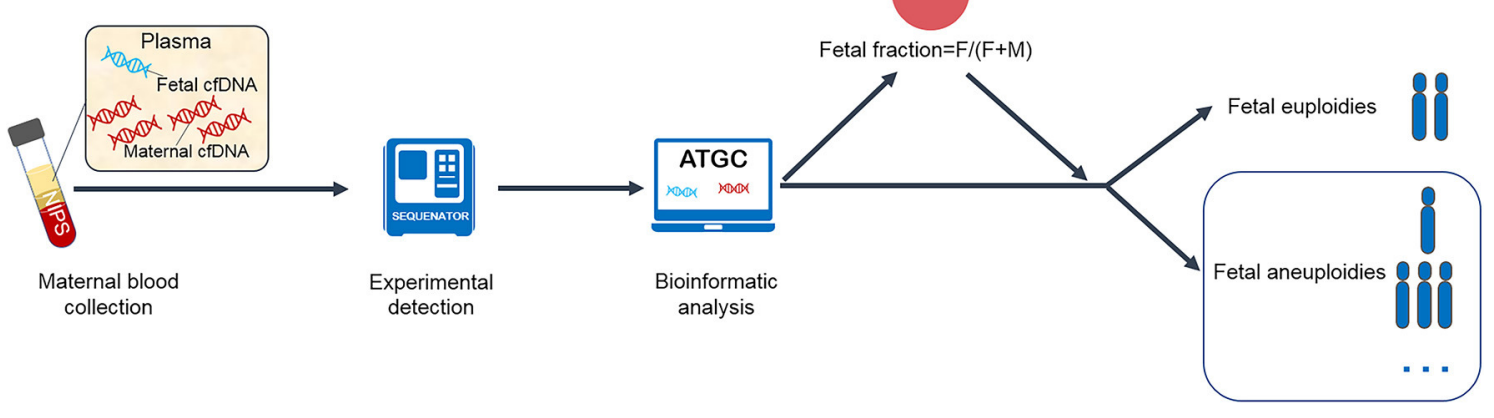

FIGURE 1 | Flow chart of noninvasive prenatal screening.

Therefore, an integrated review of FF is necessary. This review focuses on the significance and influencing factors of FF, and the management of pregnant women with failed NIPS results due to a low FF.

\section{SIGNIFICANCE OF FF}

FF is an important parameter affecting the accuracy of NIPS for chromosomal aneuploidy. FF assessment at the time of NIPS is recommended as an essential part of quality control and statistical reliability determination to ensure that sufficient cffDNA is present in maternal plasma to obtain reliable results. Usually, a FF of $2-4 \%$ is set as the minimum threshold to obtain accurate NIPS results in the laboratories $(8,9)$.

Exceptionally high and low FF have different interpretations. A low FF may indicate a higher risk of aneuploidy, ranging from 2.7 to $23.3 \%(10-12)$. If a sample's FF is below the set threshold, it will be considered a "no-call" result, which typically has a rate of $2-5 \%$. Therefore, setting a FF threshold requires a tradeoff between maximizing the statistical reliability of NIPS and minimizing the failure rate. The prevalence of aneuploidy was significantly higher in pregnant women with a FF of $<4 \%$ than in the entire cohort (4.7 vs. $0.4 \%$ ) (11). Moreover, a sufficient FF of both trisomy 21 and trisomy 18 was required for NIPS to successfully identify the mosaic case (13). As long as FF is $>4 \%$, the FF of the group with false-positive and false-negative NIPS results was not lower than that of the group with true-positive results $(14,15)$.

However, a higher FF is not always better. An unusually increased FF may predict adverse pregnancy outcomes, such as spontaneous preterm birth (16). FF elevation in the first trimester $(\mathrm{FF}=35.3 \%)$ was considered a possible marker of an abnormally invasive placenta (17). A FF of $>40 \%$ was defined as a "no call" result (9). The usefulness of cffDNA and FF in predicting adverse pregnancy outcomes has not been adequately proven. No

Abbreviations: NIPS, Noninvasive prenatal screening; FF, Fetal fraction; cffDNA, Cell-free fetal DNA; ACMG, American college of medical genetics and genomics; BMI, Body mass index; IVF, in vitro fertilization; LMWH, Low-molecular-weight heparin; PAPP-A, Pregnancy-associated plasma protein; free $\beta$-hCG, free $\beta$ subunit of human chorionic gonadotropin; HBsAg, Carriers of the hepatitis B virus surface antigen; 95\% CI, 95\% confidence interval. consensus on the maximum FF for achieving valid NIPS results is currently available.

Clinically speaking, a low trisomy score (Z-value or equivalent measure) relative to $\mathrm{FF}$ also indicated possible placental mosaicism (18). In addition, the mosaicism ratio was calculated as the ratio of the portion of cffDNA affected by aneuploidy to the total FF. A mosaicism ratio of $<0.7$ may indicate a mosaic fetal karyotype $(19,20)$.

All in all, FF within the normal range is an important link to ensure the accuracy of NIPS. Too low FF may affect the accuracy of NIPS and too high FF may indicate the presence of pregnancy complications. However, FF is not routinely reported in some laboratories. A systematic review published in 2018 included 30 studies, of which 6 examined FF in male fetuses only; 5 did not report or measure FF (21). The American College of Medical Genetics and Genomics (ACMG) recommended that all laboratories establish tests and efficacy analyses for FF and that FF be clearly identified in the NIPS report (22). Furthermore, it recommended that in the case of "no call" NIPS reports, the reason should be clarified (23). The purpose of FF report is to inform recipients that NIPS has detected sufficient cffDNA at the time of NIPS. Once FF is reported, the link between FF and NIPS results should be clarified.

\section{FACTORS AFFECTING FF}

The factors that influence FF have been of interest to various researchers over the years. Any factor that may affect the contribution of maternal or placental circulating cell-free DNA may affect FF. The effect may be either an increase in maternal circulating cell-free DNA concentrations, or a decrease in placental circulating cell-free DNA concentrations. Some biological factors are known to affect FF, while others are still under investigation. In addition to biological factors, experimental factors and FF calculation methods may also affect FF.

\section{Maternal Characteristics}

FF is affected by multiple maternal factors (Table 1). The bestknown factors affecting FF are maternal weight and gestational age. Many studies have found a negative correlation between 
TABLE 1 | Maternal factors that affect fetal fraction of circulating DNA.

\begin{tabular}{|c|c|c|c|c|}
\hline $\begin{array}{l}\text { Positive } \\
\text { correlation }\end{array}$ & Statistical values & Negative correlation & Statistical values & No correlation \\
\hline PAPP-A & $\begin{array}{l}0.1493(0.0921-0.2064),<0.001^{\dagger} \text {; Increased by } \\
\text { about } 1 \% \text { per } 0.5 \mathrm{MoM} \text { increase in PAPP-A (24); } \\
0.133(0.119-0.146),<0.0001^{\dagger}(25)\end{array}$ & Maternal body weight & $\begin{array}{l}-0.0093(-0.0114 \text { to }-0.0071),<0.001^{\dagger} \\
\text { Decreased by about } 1 \% \text { per } 10 \mathrm{~kg}(24) ; P< \\
0.001(26) ; P<0.001(27)\end{array}$ & Maternal age (26) \\
\hline \multirow[t]{9}{*}{ Free $\beta$-hCG } & $\begin{array}{l}0.0706(0.0434-0.0978),<0.001^{\dagger} \text {; Increased by } \\
\text { about } 0.4 \% \text { per } 0.5 \mathrm{MoM} \text { increase in } \beta \text {-hCG }(24) \text {; } \\
0.140(0.128-0.152),<0.0001(25)^{\dagger}\end{array}$ & $\mathrm{BMI}$ & $\begin{array}{l}-0.541(-0.697 \text { to }-0.385),<0.0001^{\dagger}(28) \\
-0.0022,<0.0001,0.1241^{\ddagger}(29) ;-0.295 \\
(-0.329 \text { to }-0.26),<0.001^{\dagger}(30)\end{array}$ & $\begin{array}{l}\text { Assisted reproductive } \\
\text { pregnancy (31) }\end{array}$ \\
\hline & & Maternal age & $\begin{array}{l}-0.202(-0.316 \text { to }-0.089), 0.0005^{\dagger}(28) \\
-0.081(-0.103 \text { to }-0.059),<0.001^{\dagger}(30) \\
P<0.05(32)\end{array}$ & $\begin{array}{l}\text { Serological screening } \\
\text { risk }(33,34)\end{array}$ \\
\hline & & Racial origin & $\begin{array}{l}\text { African American }(P=0.007)(35) ; \text { Asian } \\
\text { women }(P=0.03)(36) \text {; South Asian, } \\
-0.019(-0.032 \text { to }-0.005), 0.008^{\dagger}(25)\end{array}$ & Maternal smoking (37) \\
\hline & & $\begin{array}{l}\text { Assisted reproductive } \\
\text { pregnancy }\end{array}$ & $-0.033(-0.050$ to -0.016$),<0.001^{\dagger}(38)$ & $\begin{array}{l}\text { Low molecular weight } \\
\text { heparin (39) }\end{array}$ \\
\hline & & $\begin{array}{l}\text { Low molecular weight } \\
\text { heparin }\end{array}$ & $37.5,11.19-125.87,<0.0001^{\S}(40)$ & $\begin{array}{l}\text { Pre-existing diabetes } \\
(41)\end{array}$ \\
\hline & & Drug use & $-0.6(-1.2$ to 0.1$), 0.02^{\dagger}(42)$ & Hyperthyroidism (41) \\
\hline & & Physical activity & $\begin{array}{l}P<0.01, \text { a decrease varying from } 1-17 \\
\text { percentage points }(43)\end{array}$ & $\begin{array}{l}\text { Gestational diabetes } \\
(44)\end{array}$ \\
\hline & & Maternal diseases & $-4.1(-5.7$ to -2.5$),<0.05^{\dagger}(45)$ & HBsAg $(30,41)$ \\
\hline & & Pre-existing hypertension & RMoM of $0.85(P=0.02)(41)$ & \\
\hline
\end{tabular}

PAPP-A, serum pregnancy-associated plasma protein; Free $\beta$ - $h C G$, free $\beta$-subunit of human chorionic gonadotropin; BMI, body mass index; HBsAg, maternal carriers of the hepatitis $B$ virus surface antigen; RMoM, the ratio between mean adjust multiples of the median value and theoretical "one"; aOR, the adjusted odds ratio adjusting for BMI, hypertension, anticoagulation use, and gestational age at circulating cell-free DNA blood draw.

${ }^{\dagger}$ Regression coefficient (95\% confidence interval), P; ${ }^{\ddagger}$ Regression coefficient, P; Intercept: ${ }^{\S} \mathrm{OOR}$, (95\% confidence interval), P.

Significant at $P<0.05$.

FF and maternal body weight or body mass index (BMI). The FF of male fetuses $(26,28)$, female fetuses (26), and fetuses regardless of gender $(24,27,29,46)$ were negatively correlated with maternal body weight and BMI. After adjustment according to gestational age and maternal characteristics, BMI was found as a significant predictor of FF (47). Increased maternal body weight or BMI may increase maternal-derived circulating cell-free DNA concentrations, possibly owing to inflammation and necrosis of adipocytes (48), with or without a decrease in placenta-derived cffDNA concentrations (49). This may explain why the FF decreases with increased maternal weight or BMI. In the analysis of factors affecting FF, many researchers first corrected the FF using gestational age and BMI and then conducted multiple regression analyses. In this manner, the association bias caused by gestational age and BMI could be eliminated.

There is some controversy as to whether maternal age affects FF. FF was found to be negatively correlated with maternal age in many studies $(28,30,32)$. Moreover, after adjusting FF according to gestational age and maternal characteristics, maternal age was found to be a significant predictor of FF (47). However, no correlation was found between FF and maternal age in other studies (26). Further research is needed on the relationship between FF and maternal age.

Another intensively investigated feature of pregnancy is the racial origin. One study conducted in the United States found that pregnant women with a lower FF were more likely to be African American (35). Furthermore, pregnant South Asian women generally had a lower FF than pregnant Caucasian women (25, 36). South Asian ethnicity was also a significant predictor of FF (47). These give us a hint that race also needs to be included in the discussion of the factors affecting FF in a multiracial society.

The relationship between $\mathrm{FF}$ in assisted reproductive pregnancy and that in natural conception is under continuous investigation. The concentrations of total circulating cell-free DNA and cffDNA and FF in assisted reproductive pregnancy were considered no different from those in the natural conception (31). However, singleton in vitro fertilization (IVF) fetuses were found to have a lower FF than naturally conceived fetuses in another study, and IVF was an independent predictor of a low FF and independently associated with test failure (38). Furthermore, the FF of assisted reproductive technology-treated women with the transfer of fresh embryos (mean gestational age is 89.7 days) is lower than that of frozen embryos (mean gestational age is 90.9 days) (29). This may be attributed to the relatively young gestational age of fresh embryos.

Some studies have found that low-molecular-weight heparin (LMWH) or enoxaparin use was associated with detection failure owing to a low FF (40). Treatment with LMWH may lead to apoptosis and thus decrease FF (40). Heparin has been shown to reduce trophoblast cell apoptosis and increase trophoblast cell survival by reducing new cytokeratin epitopes and nucleosome DNA formation (50), as well as E-cadherin expression (51) and other mechanisms. However, in vitro experiments showed that instead of heparin, autoimmune diseases in pregnant women 
were independent predictors of test failure (39). The exact mechanism of the interaction between LWMH and NIPT failures remains to be elucidated. New studies linking the FF to drug use in pregnant women have also become available. The FF was significantly lower in the group taking two or more drugs than in the group not taking any drugs. The group taking metformin had a $1.8 \%$ decrease in the FF (42). In addition, the FF present in blood samples taken immediately after completing a cycling exercise was significantly lower than that taken before cycling, with a decreased range of $1-17 \%$ (43). This may be attributed to the fact that the mother's circulating cell-free DNA concentration increased owing to exercise, while the cffDNA concentration remained unchanged, leading to a decreased FF. More papers containing enough samples are needed to support this conclusion. Maternal diseases or severe immune maternal disorders, such as systemic lupus erythematosus (52), B12 deficiency (53), severe thrombocytopenia and neutropenia (54), significant $H B B$-related hemoglobinopathies (45), and preexisting hypertension (41) may also be associated with elevated maternal circulating cell-free DNA concentration or repeated detection failure owing to a low FF, while the FF improved after the disease was treated or suppressed.

Serological markers were also considered to be related to FF. Serum pregnancy-associated plasma protein (PAPP-A) and free $\beta$-subunit of human chorionic gonadotropin (free $\beta$-hCG) levels were positively correlated with FF $(24,25)$. The PAPP-A and free $\beta$-hCG levels in the test failure cohort were significantly lower than those in the success cohort. Moreover, the free $\beta$ hCG level was lower in the group with a low FF as the cause of test failure than in the group with other causes (55). However, there was no difference found in FF among high-risk, critical risk, and low-risk groups in serological screening $(33,34)$. This may reflect poor placental function or reduced placental volume. PAPP-A and free $\beta$-hCG are placenta-derived proteins that circulate in maternal blood (56). These placenta-derived proteins and cffDNA may be influenced by common factors, such as placental trophoblast cell mass (57) and the contact surface area between maternal blood and the placenta (56). This may be the reason why the PAPP-A and free $\beta$-hCG levels are associated with FF.

As has been noted, FF may be affected by many maternal factors, including BMI, maternal diseases or inflammatory states, race, and drug use. When high maternal BMI and maternal diseases or inflammatory states are present, it is necessary to be aware that FF may be low. The relationship between maternal age and assisted reproductive pregnancy and $\mathrm{FF}$ is unclear. In multiracial societies it is important to consider that FF varies between races. It is recommended to avoid the use of heparin anticoagulant blood for NIPS, and to avoid maternal use of heparin, multiple drugs and intense exercise before blood collection. The relationship between maternal factors and FF and the influencing mechanism needs further investigation. In general, maternal-induced FF changes are primarily attributed to an increase in maternal-derived circulating cell-free DNA concentrations or accompanied by a decrease in placental DNA concentrations.

\section{Fetal-Placental Characteristics}

Fetal factors can also affect FF (Table 2). Gestational age at the time of blood collection is a key factor affecting this parameter. Various studies demonstrated that FF increased with gestational age, with a positive correlation between them $(28,30,32,58,72)$. Gestational age was also found to be a significant predictor of FF (47). FF increased with gestational age throughout pregnancy. However, Hestand et al. found no correlation between FF and gestational age of up to 21 weeks (26). This may be because the increase in the FF is slow, and the increase rate is not constant. From 10 to 12.5 weeks of gestation, FF increased by $0.44 \%$ per week (46). Meanwhile, between 12.5 and 20 weeks of gestation, it increased at a rate of $0.083 \%$ per week. After approximately 20 weeks, $\mathrm{FF}$ increased steadily at a rate of $0.821 \%$. The increase rate in the first trimester was lower than that in the second trimester. In addition, it is possible that although FF increased slightly with gestational weeks, it also decreased temporarily owing to the increase in maternal body weight (73). The fetal crown-rump length, an important parameter for calculating gestational age in the first trimester, as well as FF, also increases $(7,25,34)$.

Research on FF in cases of multiple pregnancies remains limited (74). A large prospective, multicenter study demonstrated a $\mathrm{FF}$ range of $3-36 \%$ in twin pregnancies, with a mean $\mathrm{FF}$ of $12.2 \%$ (75). The optimal minimum FF that is valid for traditional NIPS in twin pregnancies should be $8 \%$, although it is not certain that a sufficient FF is released from each fetus (76). The FF per twin was lower in some studies $(59,60)$ and higher in others $(66)$, and the difference in FF contribution of each fetus may reach up to two-fold $(77,78)$. The existence of dichorionic twins was one of the influencing factors for the overall risk of test failure (9). The existence of dizygotic (DZ) twins was moderately correlated with FF. Moreover, the total FF of DZ twins and monozygotic twins was 35 and $26 \%$ higher than that of singleton fetuses, respectively $(64,65)$. The FF contribution per fetus in DZ twins was 32\% less on average than that in singletons. Therefore, for twin pregnancies, establishing the zygosity of twins and determining FF in each fetus of DZ twins are important to achieve the optimal value of NIPS for aneuploidy screening.

In a case of a miscarriage of one twin, the DNA of the aborted fetus affected the FF. Vanishing twin is one of the reasons for testing failure. And the gestational age of blood sampling may be different between the IVF and natural conception for vanishing twin pregnancies (79). Some false-negative aneuploid cases detected through NIPS were attributed to a vanishing twin (80). Some testing platforms calculate the proportion of Ychromosome reads to evaluate the FF. When the Y chromosome is at a static threshold, the Y-chromosome method will be used to calculate the FF. If the male fetus fails to live, and the living fetus is female, Y-chromosome contamination will gradually decrease as the pregnancy progresses, and the total $\mathrm{FF}$ will increase. Therefore, blood sampling after 14 weeks of gestation for NIPS may reduce the impact of a vanishing twin (81).

Pregnant women with female fetuses who undergo NIPS seem to have a higher FF in some studies (24). There was a marginal correlation $(p=0.067)$ between fetal trisomy and a low FF. However, there was no significant increase in the incidence of trisomy in the FF group with low FF detection failure (61). 
TABLE 2 | Fetal-Placental factors that affect the fetal fraction of circulating DNA.

\begin{tabular}{|c|c|c|c|c|}
\hline $\begin{array}{l}\text { Positive } \\
\text { correlation }\end{array}$ & Statistical values & Negative correlation & Statistical values & No correlation \\
\hline Gestational age & $\begin{array}{l}0.959(0.735 \text { to } 1.183),<0.0001^{\dagger}(28) ; 0.165 \\
(0.127 \text { to } 0.204),<0.001^{\dagger}(30) ; P<0.05(32) ; \\
\text { Fetal fraction_twin pregnancies (gestational } \\
\text { age) }=0.646^{\star} \text { gestational age }+4.360, R= \\
0.52^{\ddagger}(58)\end{array}$ & Trisomy 18 & $P=0.04$ (27); Ratio ${ }^{\S} 0.71, P<0.001$ (12) & Gestational age (26) \\
\hline $\begin{array}{l}\text { Fetal } \\
\text { crown-rump } \\
\text { length }\end{array}$ & $\begin{array}{l}0.005(0.002 \text { to } 0.009), 0.001^{\dagger}(7) ; 0.001 \\
\text { (4.7E-04 to } 0.001),<0.0001^{\dagger}(25) ; \text { Pearson } \\
\text { correlation } R^{2}=0.023, P=0.037 \text { (34) }\end{array}$ & Trisomy 13 & $P=0.004(27)$ & $\begin{array}{l}\text { Nuchal translucency } \\
\text { thickness }(15,33,37)\end{array}$ \\
\hline Female fetus & $\begin{array}{l}\text { About } 1 \% \text { higher in pregnancies with female } \\
\text { fetuses (24) }\end{array}$ & Twin pregnancies & $\begin{array}{l}-4.575(-7.257 \text { to }-1.894), 0.0008^{\dagger}(28) ; P \\
<0.001(59) ; P<0.0001(60)\end{array}$ & Fetal trisomy (61) \\
\hline Trisomy 21 & Ratio $\$ 1.17, P<0.001$ (12) & $\begin{array}{l}\text { Hypertensive disorders of } \\
\text { pregnancy/pregnancy } \\
\text { induced hypertension }\end{array}$ & $\begin{array}{l}10.9 \text { vs. } 12.4, P<0.0001 \text { (62); Risk ratios }= \\
1.6 \text { [95\%Cl: } 1.003-2.6](63) ; P=0.001(35)\end{array}$ & Low birth weight (35) \\
\hline $\begin{array}{l}\text { Twin } \\
\text { pregnancies }\end{array}$ & $\begin{array}{l}\text { Pearson correlation coefficient }=0.66, P< \\
0.0001 \text { (64); } P=0.0097 \text { (65); } P=0.001 \text { (66) }\end{array}$ & Preeclampsia & $\begin{array}{l}\text { Risk ratios }=3.3 \text { [95\%Cl: } 1.2-8.9](63) ; \\
\text { Adjusted } \mathrm{OR}=2.06,95 \% \mathrm{Cl}: \\
\text { 1.07-3.98 (67); OR }=0.59,95 \% \mathrm{Cl}: \\
\text { 0.35-0.99, } P=0.048 ; \text { and } \mathrm{OR}=0.27 \\
95 \% \mathrm{Cl}: 0.08 \text { to } 0.96, P=0.044)(62)\end{array}$ & Placental abruption (35) \\
\hline \multirow[t]{4}{*}{ Preterm birth } & $\begin{array}{l}\text { Adjusted OR 4.59, 95\% Cl 1.39-15.2; adjusted } \\
\text { OR 22.0, 95\% Cl 5.02-96.9 (16) }\end{array}$ & Fetal growth restriction & $\begin{array}{l}\mathrm{OR}=0.87,95 \% \mathrm{Cl}: 0.79-0.96, P= \\
0.006(68) P<0.001(69)\end{array}$ & $\begin{array}{l}\text { Placenta accrete and } \\
\text { placenta previa (70) }\end{array}$ \\
\hline & & Preterm birth & $\begin{array}{l}P=0.002(35) ;<34 \text { weeks' gestation: } \\
\text { adjusted } \mathrm{OR}=3.09,95 \% \mathrm{Cl}: 1.21-7.92(67)\end{array}$ & $\begin{array}{l}\text { Intrahepatic cholestasis } \\
\text { of pregnancy (67) }\end{array}$ \\
\hline & & Low birth weight & $\begin{array}{l}\text { Adjusted OR of } 2.32(95 \% \mathrm{Cl} 1.15-4.67) \text { for } \\
\text { birth weight } \leq 10 \text { th percentile }(P=0.02) \\
\text { and aOR of } 3.73(95 \% \mathrm{Cl} 1.40-9.03) \text { for birth } \\
\text { weight } \leq 5 \text { th percentile }(P=0.004)(71) \text {; } \\
<2,500 \mathrm{~g} \text { : adjusted } \mathrm{OR}=2.50,95 \% \mathrm{Cl} \text { : } \\
1.01-6.17 \text { (67) }\end{array}$ & $\begin{array}{l}\text { Gestational diabetes } \\
\text { mellitus }(44,67)\end{array}$ \\
\hline & & Placental compromise & Risk ratios $=1.6$ and $95 \% \mathrm{Cl}: 1.1-2.2$ (63) & \\
\hline
\end{tabular}

95\% Cl, 95\% confidence interval.

${ }^{\dagger}$ Regression coefficient (95\% confidence interval), $P$; ${ }^{\ddagger}$ The corresponding regression equations; ${ }^{\S}$ Ratio, median fetal fraction for subgroup/median fetal fraction for euploid pregnancies. IOR, odds ratio.

Significant at $P<0.05$.

Conversely, FF was higher in the trisomy 21 group and lower in the trisomy 18 and trisomy 13 groups than in the euploid group, which may complicate the efficacy of NIPS in detecting trisomy 18 and trisomy $13(12,27)$.

A low FF was also found to be associated with an increased risk of placenta-related disorders and adverse perinatal outcomes. Pregnant women with an increased risk of hypertensive disorders of pregnancy and preeclampsia and those with preeclampsia with severe features had lower FF in early pregnancy (62), which was similar to the results of another research (63). Moreover, FF below the 10th percentile was associated with an increased risk of preeclampsia and early preterm birth $<34$ weeks (67), and FF greater than or equal to the 95th percentile was also associated with an increased risk of preterm delivery (16). Furthermore, FF below the 5th percentile was associated with an increased risk of low birth weight $(67,71)$. In addition, intrauterine growth restriction under 5th percentile was correlated with low FF (OR $=0.87$, IC 95\% 0.79-0.96, $P=0.006)$ (68), and the FF of pregnant women with early-onset growth restriction $(2.00 \pm 2.23 \%)$ was significantly lower than the expected FF $(18.97 \pm 10.17 \%)$ (69). This is consistent with the typical placental disorders of early fetal growth restriction. However, other complications, including placental abruption (35), placenta accrete and placenta previa (70), intrahepatic cholestasis of pregnancy (67), and gestational diabetes mellitus $(44,67)$, were not associated with FF.

In sum, FF may be affected by gestational age, fetal crownrump length, fetal sex, fetal karyotype, and twin pregnancies, and FF is associated with an increased risk of placenta-related disorders and adverse perinatal outcomes. FF is positively correlated with gestational age, so NIPS should be performed at the appropriate gestational age. The position statement issued by the ACMG in 2016 indicated that NIPS can be used to screen fetuses for trisomy 21, trisomy 18 , and trisomy 13 at a gestational age of 9-10 weeks, or more (22). For twin pregnancies, it is important to establish the zygosity of the twins and determine the FF of each fetus in DZ twins. Meanwhile, blood sampling after 14 weeks of gestation may reduce the effect of a vanishing twin (81). Because of these factors that may affect FF, clinicians should obtain as much detail as possible regarding the characteristics of the pregnant woman and fetus when considering NIPS. In this manner, comprehensive judgment can be made to ensure 
TABLE 3 | Experimental factors that are associated with fetal fraction of circulating DNA.

\begin{tabular}{|c|c|c|c|c|}
\hline $\begin{array}{l}\text { Positive } \\
\text { correlation }\end{array}$ & Statistical values & Negative correlation & Statistical values & No correlation \\
\hline \multirow[t]{3}{*}{$\begin{array}{l}\text { Uniquely } \\
\text { mapped reads }\end{array}$} & $2.292(1.462$ to 3.122$),<.0001^{\dagger}(28)$ & $\begin{array}{l}\text { Circulating cell-free DNA } \\
\text { fragment size }\end{array}$ & $-0.695(-0.78$ to -0.61$),<0.0001^{\dagger}(28)$ & Hemolysis (89) \\
\hline & & $\begin{array}{l}\text { Circulating cell-free DNA } \\
\text { concentration }\end{array}$ & $-1.05(-2.45$ to 0.34$),<0.0001^{\dagger \S}(90)$ & \\
\hline & & Library concentration & $-4.86(-6.48$ to -3.23$),<0.0001^{+I I}(90)$ & \\
\hline Z-value & $\begin{array}{l}\beta=0.77, \mathrm{SE}=0.04, P<1^{\star} 10-16(91) r T 21^{\ddagger} \\
=0.905, P T 21=0.00 ; r T 18^{\ddagger}=0.887, P T 18 \\
=0.00 ; r T 13^{\ddagger}=0.858, P T 13=0.01(92)\end{array}$ & & & \\
\hline
\end{tabular}

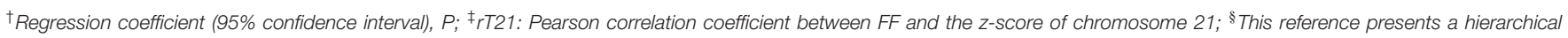

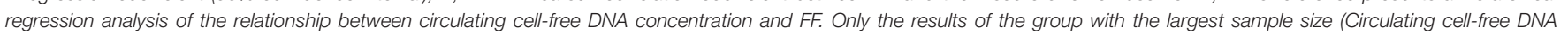
Concentration $<0.121 \mathrm{ng} / \mathrm{ul}$ ) was shown here; "II Only the results of the group with the largest sample size (Library concentration > $10.701 \mathrm{ng} / \mathrm{ul}$ ) was shown here.

Significant at $P<0.05$.

a sufficient FF and consequently an accurate NIPS screening for aneuploidy.

\section{Experimental Factors}

Some pre-analytical aspects need to be considered. The serum FF was lower than the plasma FF, so plasma DNA is recommended for NIPS (82). Owing to maternal and fetal DNA fluctuations, FF in maternal plasma showed a downward trend after 2 years of storage at $-25^{\circ} \mathrm{C}$, decreasing after 3 years. However, the FF of the extracted DNA stored at $-25^{\circ} \mathrm{C}$ for 18 months did not change, and the FF of the extracted DNA stored for 3 years increased by $27 \%$ compared with that detected immediately (83). After freezing, the plasma GC content in samples from pregnant women increased, and the $\mathrm{FF}$, unit reads/total reads ratio, and $\mathrm{Z}$ score of trisomy 21 in male fetuses decreased, resulting in decreased detection accuracy (84). Some scholars have also studied changes in the FF caused by the use of different blood collection tubes. The proportion of cffDNA decreased steadily with the increase in storage time in conventional K3EDTA tubes, with a significant decrease of 48.5 and $65.7 \%$ on day 2 and day 3 , respectively (85). A significant decrease of $80 \%$ was observed on day 4. An increase in the concentration of total circulating cell-free DNA in the plasma stored in circulating cell-free DNA BCT tubes at $4^{\circ} \mathrm{C}$ also resulted in a decrease in FF $(86,87)$. The FF in samples stored in STRECK BCT tubes may be higher than that in samples stored in EDTA tubes (88). STRECK BCT tubes may be the best blood collection tubes. Therefore, the impact of sample storage on FF before and during sample testing should be carefully considered, especially re-inspection of the frozen samples. Excessive transport or sample storage temperatures may rupture the mother's white blood cells, releasing more maternal cfDNA and resulting in a decrease in FF.

The experimental process of NIPS includes DNA extraction, library construction, and sequencing, and some test data in the experimental process may also affect FF (Table 3). FF was negatively correlated with the circulating cell-free DNA concentration, library concentration, and circulating cell-free DNA fragment size and positively correlated with uniquely mapped reads $(28,90)$. Therefore, when the circulating cell-free DNA and library concentrations are too high, the amount of fetal-derived cffDNA may be reduced, leading to a decrease in FF and thus affecting detection. The $\mathrm{Z}$-value may also be positively correlated with FF $(91,92)$. Operator variation in performing the experiments during the testing may also affect FF, but it is not easy to quantify and standardize it. It may be considered that inter-and intra-operator variation in performing experiments during the testing is reflected in the data of the experimental process, such as circulating cell-free DNA concentration, library concentration, and uniquely mapped reads.

To sum up, FF may be associated with circulating cell-free DNA fragment size, circulating cell-free DNA concentration, library concentration, uniquely mapped reads, and $\mathrm{Z}$ value. Therefore, laboratory staff should comprehensively analyze the data in the experimental process when examining the results.

\section{Methods for Calculation FF}

Measurement of FF is essential for quality control. The approaches currently used for evaluating FF are summarized in Table 4. Among them, FF calculation methods based on the Y chromosome are the most common. They are also currently recognized as the most likely gold standard calculation method. However, these methods are limited to the calculation of FF in male fetuses only. Many studies have compared different FF calculation methods, showing significant differences in the FF among them.

One study compared between DEFRAG (95) [including DEFRAG_W (entire Y-chromosome method) and DEFRAG_S (a subset Y-chromosome method)], SANEFALCON (113), and SeqFF (107) (including ENET (119) and WRSC (120) scores) tests for FF and discovered that only DEFRAG_W could accurately analyze fetal DNA distribution (26). Moreover, DEFRAG_S was more likely to report no or a high FF. However, SeqFF, ENET, and WRSC performed better in samples with a high FF. In addition, SANEFALCON had high false positives rates for FF. The SeqFF method cannot be limited to the evaluation of FF in male or female fetuses but may underestimate this parameter in high and low limits (105). Therefore, Hestand et al. concluded that DEFRAG_W was the best-tested method for calculating FF in male fetuses and SeqFF in female fetuses, although the latter still needs improvement (26). Moreover, the FF range in the 
TABLE 4 | Approaches for evaluating fetal fraction (93, 94).

\begin{tabular}{|c|c|c|c|c|}
\hline Approaches & Algorithm name & References & Advantages & Disadvantages \\
\hline \multicolumn{5}{|l|}{ Sex chromosome- based } \\
\hline \multirow[t]{4}{*}{ Y Chromosome based } & & & Easy and precise & For male fetuses only, not female fetuses \\
\hline & $\begin{array}{l}\text { Y Chromosome } \\
\text { based/FFY }\end{array}$ & $(3,4,34,92)$ & & \\
\hline & DEFRAG & $(26,95,96)$ & & \\
\hline & CSMART & (73) & & \\
\hline \multirow[t]{2}{*}{$\begin{array}{l}\text { X-chromosome and } Y \\
\text { Chromosome based }\end{array}$} & PREFACE & $(97)$ & $\begin{array}{l}\text { Training with a limited amount of } \\
\text { retrospective data }\end{array}$ & NA \\
\hline & BAYINDIR & $(95,98)$ & & \\
\hline SNP-based & & & Precise & $\begin{array}{l}\text { Extra parental SNP information may not be } \\
\text { readily available }\end{array}$ \\
\hline $\begin{array}{l}\text { Polymorphic loci quantified with } \\
\text { microarray or sequencing }\end{array}$ & DANSR & $(99-101)$ & & \\
\hline SNP loci & & $(102,103)$ & & \\
\hline \multirow[t]{2}{*}{ Insertion/deletion polymorphisms } & & $(104)$ & & \\
\hline & SNPFF & $(105,106)$ & & Underestimated FF less than 7\% \\
\hline Sequence read count & SeqFF & $(26,80,95,107)$ & $\begin{array}{l}\text { Only sequencing of maternal circulating } \\
\text { cell-free DNA; Applicable to regular } \\
\text { noninvasive prenatal screening; sequencing } \\
\text { is only required on a single end }\end{array}$ & $\begin{array}{l}\text { Accuracy is not good at low FF; training } \\
\text { with a large amount of retrospective data }\end{array}$ \\
\hline Differential methylation & & $(108-110)$ & Precise & $\begin{array}{l}\text { Further cost is added by whole-genome } \\
\text { bisulfite sequencing; affected by } \\
\text { methylation-sensitive restriction enzyme } \\
\text { digestion and bisulfite transformation }\end{array}$ \\
\hline Fragment size based & & $(111,112)$ & $\begin{array}{l}\text { Only sequencing of maternal circulating } \\
\text { cell-free DNA; Applicable to regular } \\
\text { noninvasive prenatal screening }\end{array}$ & $\begin{array}{l}\text { Further cost is added by paired-end } \\
\text { next-generation sequencing; moderate } \\
\text { accuracy }\end{array}$ \\
\hline Nucleosome profile & SANEFALCON & $(26,95,96,113)$ & $\begin{array}{l}\text { Only sequencing of maternal circulating } \\
\text { cell-free DNA }\end{array}$ & $\begin{array}{l}\text { Lower accuracy; training with high-depth } \\
\text { sequencing data }\end{array}$ \\
\hline \multicolumn{5}{|l|}{ Others } \\
\hline $\begin{array}{l}\text { Maternal plasma DNA sequencing } \\
\text { data with parental genotypes }\end{array}$ & & $(114,115)$ & Direct and precise & $\begin{array}{l}\text { Hindered by the requirement of parental } \\
\text { genotypes }\end{array}$ \\
\hline MPS deduction: sequence counts & FetalQuant & $(116)$ & $\begin{array}{l}\text { Targeting only the maternal circulating } \\
\text { cell-free DNA; Precise }\end{array}$ & $\begin{array}{l}\text { The sequencing depth is required to be as } \\
\text { high as } \sim 120 \times\end{array}$ \\
\hline $\begin{array}{l}\text { Shallow-depth sequencing of } \\
\text { maternal plasma DNA coupled with } \\
\text { maternal genotypes }\end{array}$ & FetalQuant $^{S D}$ & $(117)$ & $\begin{array}{l}\text { Only shallow depth sequencing of maternal } \\
\text { circulating cell-free DNA; Precise }\end{array}$ & $\begin{array}{l}\text { The maternal genotype is required; } \\
\text { Parameters of the model need to be reset } \\
\text { according to sequencing and genotyping } \\
\text { platform }\end{array}$ \\
\hline $\begin{array}{l}\text { Shallow-coverage sequencing of } \\
\text { maternal plasma DNA }\end{array}$ & FF-QuantSC & $(118)$ & & \\
\hline
\end{tabular}

SANEFALCON method was narrower than that in the DEFRAG method, and the assay-based method involving methylated RASSF1A promoters $(96,108)$. However, the DEFRAG assay can only detect FF in male fetuses, while the RASSF1A assay can detect the FF in both male and female fetuses but requires additional PCR steps.

Compared with the most reliable method FFY $(4,34)$, SNPFF underestimated FF by 7\% (105), which was similar to the results of another study in which SNPFF underestimated FF by $10 \%$ (106). Moreover, Song et al. found that SNPFF underestimated the full range of FF (73). The SeqFFY method is equivalent to the FFY method in the case of a male fetus, and the FFY method corrects the SeqFF method in the case of a female fetus. In addition, the SNP-based FF calculation method is more costly. The sequence read count-based FF assessment methods (such as SeqFF) are based on the theory that cffDNA is more likely to come from regions with increased euchromatin DNA structure. Reads aligned within certain autosomal regions are counted and FF is calculated by weighting (107). The SNPbased FF evaluation method is to perform high-coverage targeted sequencing for highly polymorphic SNPs and evaluate FF from the SNP locations of maternal homozygous genes and fetal heterozygous genes (105). That's the difference between the two approaches. Moreover, FF calculated by fragment size-based method is highly consistent with that calculated by FFY (111). The fragment size-based method is based on the fact that the length of DNA fragments derived from the placenta is smaller than that of maternal origin. Both maternal and fetal cffDNA 
fragment size distributions show a series of peaks, including the main peak of $166 \mathrm{bp}$ and a small peak of $143 \mathrm{bp}$, as well as peaks of less than $143 \mathrm{bp}$ at intervals of $10 \mathrm{bp}$. The biggest difference between fetal cffDNA and maternal cfDNA is the decrease in the ratio of fragments of $166 \mathrm{bp}$ and the increase in the ratio of fragments less than 150bp (114). In addition, the consistency of the Y-chromosomal-based FF assessment methods is higher than that of methods that can also be used to measure the FF in female fetuses. The consistency was higher when only specific regions in the Y-chromosome were considered, including that of the DEFRAGb and BAYINDIRb (98) methods (95). The DEFRAGb method effectively identified a low FF. The two methods available for male and female fetuses were not as accurate as of the Y-chromosome method, and SANEFALCON was less effective than SeqFF. However, SANEFALCON also performed best in measuring a low FF, even better than did DEFRAGb. Therefore, the use of multiple FF calculation methods is recommended. For example, the SANEFALCON method was used to exclude samples with a low FF; thereafter, the DEFRAGb method and the SeqFF method were used to measure FF in male and female fetuses, respectively (95).

Re-evaluations using the FF-QuantSC method and analysis of distribution patterns of Y-chromosome reads may lead to more accurate results for samples with a repeatedly low FF, especially for derived chromosomes containing part of the Y-chromosome (121). In this manner, rare cases of sex reversal caused by $S R Y$ translocation could avoid being misjudged as detection failures by Y-chromosome-based FF calculation methods.

Each FF evaluation method has its advantages and disadvantages; however, it is difficult to determine which method performs the best or the worst. No method is perfectly efficient, and no method is inefficient. The FF calculation methods used by different testing platforms may differ, and the FF calculated by different methods is not currently directly comparable. Some methods also develop variants as experiments evolve. Moreover, different bioinformatics algorithms may affect the FF calculation methods (93). Therefore, it is important to be specifically based on the different methods that different laboratories use. It is not sufficient to use a single FF evaluation method. Instead, it is best to use a combination of multiple methods for FF evaluation: Instead of simply using FF thresholds as a quality control criterion, focusing on improving FF detection methods used by the testing platform takes precedence. There is also an urgent need for standardization of FF test methods and reporting $(122,123)$.

\section{MANAGEMENT OF PREGNANT WOMEN WITH FAILED RESULTS OWING TO A LOW FF}

It is important to address the issue of a low FF. Many studies have improved existing FF calculation methods. These improvements include enrichment of cffDNA, optimization of sequencing conditions, improvement of bioinformatics algorithms, and maximization of differences in maternal and fetal DNA fragment sizes $(117,124-128)$. Xue et al. used E-gel-based size selection
BOX 1 | Fetal fraction toolbox for genetic counselors and clinical laboratories providing NIPS:

\section{Questions for genetic counselors to ask themselves}

What are the basic characteristics of the pregnant woman and fetus that need to be collected before conducting NIPS?

Are there maternal or fetal factors that may cause increased FF detected by NIPS?

Are there maternal or fetal factors that may cause decreased FF detected by NIPS?

How to manage pregnant women with failed results owing to a low FF?

Questions for clinical laboratories providing NIPS to ask themselves

Is FF routinely calculated and is a minimum detection limit for the FF calculation set?

What is the calculation method used and what are its advantages and disadvantages?

Is FF routinely reported in NIPS reports and is its significance indicated in clinical reports?

What is the detection failure rate owing to a low FF?

Is the cause of test failure reported?

What is the detection success rate of blood redrawn after test failure?

Are additional follow-up tests provided after NIPS fails?

NIPS to screen for and exclude shorter circulating cell-free DNA fragments from the total circulating cell-free DNA and then evaluated FF through Y-chromosome reads, which increased FF by $99-359 \%$ (128). After optimization, FF in a twin NIPS false-negative sample was increased by $23.1 \%$. Abnormalities in two false-negative samples owing to confined placental mosaicism were also detected. Such improvements can improve the FF detection accuracy but could also increase the cost. Therefore, laboratories need to consider a trade-off. For clinical laboratories, there are a variety of calculation methods for FF, and many questions should be considered (Box 1). These are the clinical laboratory needs to be concerned. Since FF provides significant information, routine FF calculation is necessary when performing NIPS, although there is some debate regarding whether FF should be routinely reported. Every laboratory should establish a personalized test for FF determination and interpretation and establish a minimum detection threshold for obtaining valid NIPS results. Laboratory personnel can also predict in advance whether there will be a low FF according to the positive and negative correlation factors during the experiment so that the decrease of FF caused by the experimental factors could be minimized to some extent through the improvement of the experiment.

Genetic counselors are supposed to focus on what they need to know (Box 1). Various NIPS and FF evaluation methods are currently available, and genetic counselors do not need to know the specific methods. However, they are expected to be aware that the FF obtained through different methods and different laboratories cannot be directly compared, emphasizing the need for caution when interpreting NIPS reports. When collecting information on pregnant women, genetic counselors are supposed to make a basic judgment on whether a high 


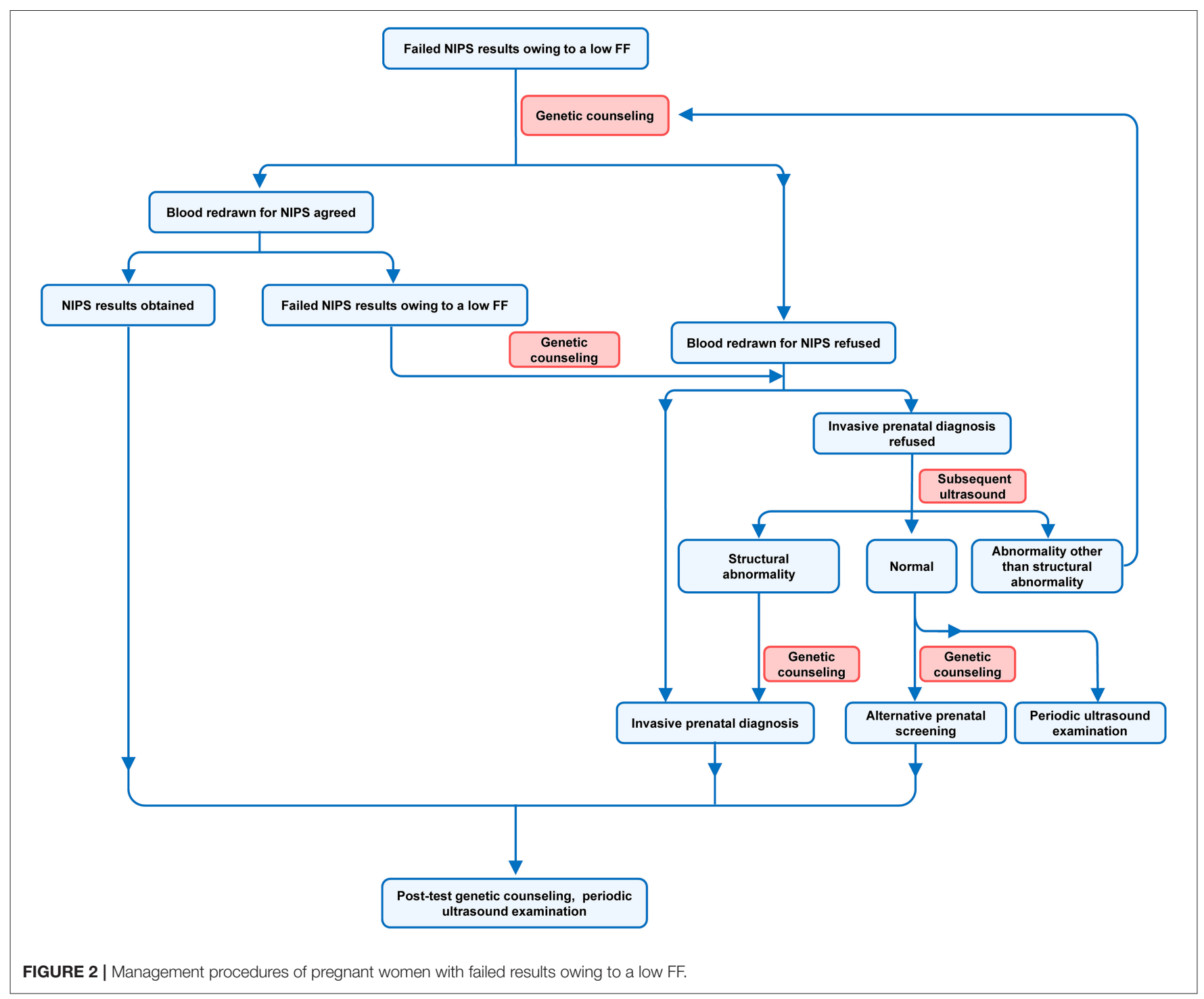

or low FF will be obtained in NIPS and how to manage the result. When a pregnant woman receives a "no call" NIPS result, subsequent genetic counseling is recommended (Figure 2). Genetic counselors are expected to discuss the factors that are associated with fetal fraction of circulating DNA and also provide professional advice on the cause of test failure. The reason for a low FF may be the increase of factors negatively related to FF, such as BMI, or the decrease of factors positively related to FF, such as gestational age. Pregnant women ought to be advised that NIPS failure may be influenced by factors affecting FF or may indicate an increased risk of fetal aneuploidy. Pregnant women can decide to have their blood redrawn for NIPS and attempt to avoid factors that may affect FF. However, some factors affecting FF are unavoidable; thus, a $40-50 \%$ test failure rate from resampling remains feasible (94). The NIPS success rate from resampling was mainly determined by the FF of the initial sample and the pregnant woman's weight (102). Based on the FF of the initial sample, maternal weight, and interval between blood collections, a personalized assessment of the test success rate of resampling for each pregnant woman could be considered (129). This is attributed to the strong correlation between the FF of the same blood sample from the same individual person and the FF of different blood samples (46). Based on the resampling results, subsequent management strategies are then suggested by genetic counselors.

Invasive prenatal diagnosis remains an option if a pregnant woman is unwilling to have her blood redrawn for NIPS. If the pregnant woman opts against a redraw and an invasive prenatal diagnosis, the decision is based on the subsequent ultrasound results and the pregnant woman's judgment. If the ultrasound results are normal, alternative prenatal screening, such as combined first-trimester screening, may be an option (94). However, if the ultrasound results are abnormal, the pregnant woman may need to have her blood redrawn for NIPS or undergo an invasive prenatal diagnosis. If the ultrasound results present a structural abnormality, a direct invasive prenatal 
diagnosis is recommended. Periodic ultrasound examination is necessary regardless of whether blood is redrawn for NIPS. If the NIPS still calculates a low FF following the redraw, invasive prenatal diagnosis is recommended, and regular ultrasound should be maintained.

In samples with a significantly reduced FF, the most common abnormalities were trisomy 18, trisomy 13 , and triploidy $(12,25)$. However, these abnormal fetuses will likely present abnormalities on subsequently targeted ultrasound, such as a heart defect or limb abnormality $(130,131)$. Therefore, it is not necessary to perform invasive prenatal diagnosis for every pregnancy whose NIPS test fails owing to a low FF. However, if this NIPS test failure is secondary to other highrisk outcomes, such as advanced age or serological screening, the recommendation for invasive prenatal diagnosis may be appropriate. In general, it is essential that the genetic counselors closely liaise with the clinical laboratories to manage pregnant women who received failed NIPS results. It is recommended that the clinical laboratories report the cause of test failure and that the genetic counselors conduct comprehensive genetic counseling for pregnant women.

Therefore, genetic counseling of pregnant women with failed results owing to a low FF requires the full involvement of the genetic counselors. After failed NIPS results due to low FF obtained, the genetic counselors are supposed to make recommendations based on the characteristics of each pregnant woman and the test results during pregnancy, then the pregnant woman could choose further tests based on the professional information provided by the genetic counselors and her demands.

\section{REFERENCES}

1. Lo YM, Corbetta N, Chamberlain PF, Rai V, Sargent IL, Redman CW, et al. Presence of fetal DNA in maternal plasma and serum. Lancet. (1997) 350:485-7. doi: 10.1016/S0140-6736(97)02174-0

2. Devaney SA, Palomaki GE, Scott JA, Bianchi DW. Noninvasive fetal sex determination using cell-free fetal DNA: a systematic review and metaanalysis. JAMA. (2011) 306:627-36. doi: 10.1001/jama.2011.1114

3. Chiu RW, Chan KC, Gao Y, Lau VY, Zheng W, Leung TY, et al. Noninvasive prenatal diagnosis of fetal chromosomal aneuploidy by massively parallel genomic sequencing of DNA in maternal plasma. Proc Natl Acad Sci USA. (2008) 105:20458-63. doi: 10.1073/pnas.0810641105

4. Fan HC, Blumenfeld YJ, Chitkara U, Hudgins L, Quake SR. Noninvasive diagnosis of fetal aneuploidy by shotgun sequencing DNA from maternal blood. Proc Natl Acad Sci USA. (2008) 105:16266-71. doi: 10.1073/pnas.0808319105

5. Palomaki GE, Kloza EM, Lambert-Messerlian GM, Haddow JE, Neveux LM, Ehrich M, et al. DNA sequencing of maternal plasma to detect Down syndrome: an international clinical validation study. Genet Med. (2011) 13:913-20. doi: 10.1097/GIM.0b013e3182368a0e

6. Gil MM, Quezada MS, Revello R, Akolekar R, Nicolaides KH. Analysis of cell-free DNA in maternal blood in screening for fetal aneuploidies: updated meta-analysis. Ultrasound Obstet Gynecol. (2015) 45:249-66. doi: 10.1002/uog.14791

7. Ashoor G, Syngelaki A, Poon LC, Rezende JC, Nicolaides KH. Fetal fraction in maternal plasma cell-free DNA at 11-13 weeks' gestation: relation to maternal and fetal characteristics. Ultrasound Obstet Gynecol. (2013) 41:2632. doi: 10.1002/uog.12331

\section{CONCLUSIONS}

cffDNA is the cell-free fetal DNA present in maternal plasma and forms the basis of NIPS. FF is an important quality control link of NIPS. It is necessary to have a specific understanding of FF to maximize the value of NIPS. A high or low FF has different meanings, and a normal range of FF is very important for obtaining accurate NIPS results. Furthermore, FF is affected by many factors, including maternal characteristics, fetal-placental characteristics, experimental factors, and calculation methods. Both genetic counselors and laboratory staff should contribute to obtaining accurate NIPS results. When test failure of NIPS due to low FF is obtained, the genetic counselors and clinical laboratory are supposed to work together to manage the pregnant women. Going forward, a combined effort is needed to reduce NIPS failure owing to a low FF.

\section{AUTHOR CONTRIBUTIONS}

CD and SL had the idea for the article. CD performed the literature search and data analysis and drafted the work. SL critically revised the work. All authors contributed to the article and approved the submitted version.

\section{FUNDING}

This work was supported by the National Key Research and Development Program of China (2018YFC1002203) and the Technology Research and Development Program of the Science and Technology Department of Sichuan Province, China (2021YFS0078).
8. Fiorentino F, Bono S, Pizzuti F, Mariano M, Polverari A, Duca S, et al. The importance of determining the limit of detection of non-invasive prenatal testing methods. Prenat Diagn. (2016) 36:304-11. doi: 10.1002/pd.4780

9. Guy GP, Hargrave J, Dunn R, Price K, Short J, Thilaganathan B. Secondary non-invasive prenatal screening for fetal trisomy: an effectiveness study in a public health setting. Bjog. (2021) 128:440-6. doi: 10.1111/1471-0528. 16464

10. Pergament E, Cuckle H, Zimmermann B, Banjevic M, Sigurjonsson S, Ryan A, et al. Single-nucleotide polymorphism-based noninvasive prenatal screening in a high-risk and low-risk cohort. Obstet Gynecol. (2014) 124:2108. doi: 10.1097/AOG.0000000000000363

11. Norton ME, Jacobsson B, Swamy GK, Laurent LC, Ranzini AC, Brar H, et al. Cell-free DNA analysis for noninvasive examination of trisomy. $\mathrm{N} \mathrm{Engl} \mathrm{J}$ Med. (2015) 372:1589-97. doi: 10.1056/NEJMoa1407349

12. Palomaki GE, Kloza EM, Lambert-Messerlian GM, van den Boom D, Ehrich M, Deciu C, et al. Circulating cell free DNA testing: are some test failures informative? Prenat Diagn. (2015) 35:289-93. doi: 10.1097/01.ogx.0000470818.76451.4a

13. Mao J, Wang T, Wang BJ, Liu YH, Li H, Zhang J, et al. Confined placental origin of the circulating cell free fetal DNA revealed by a discordant noninvasive prenatal test result in a trisomy 18 pregnancy. Clin Chim Acta. (2014) 433:190-3. doi: 10.1016/j.cca.2014.03.011

14. Zhang H, Gao Y, Jiang F, Fu M, Yuan Y, Guo Y, et al. Noninvasive prenatal testing for trisomies 21,18 and 13: clinical experience from 146,958 pregnancies. Ultrasound Obstet Gynecol. (2015) 45:5308. doi: 10.1002/uog.14792

15. Scott FP, Menezes M, Palma-Dias R, Nisbet D, Schluter P, da Silva Costa F, et al. Factors affecting cell-free DNA fetal fraction and the 
consequences for test accuracy. J Matern Fetal Neonatal Med. (2018) 31:1865-72. doi: 10.1080/14767058.2017.1330881

16. Dugoff L, Barberio A, Whittaker PG, Schwartz N, Sehdev H, Bastek JA. Cell-free DNA fetal fraction and preterm birth. Am J Obstet Gynecol. (2016) 215:231.e231-7. doi: 10.1016/j.ajog.2016.02.009

17. Wertaschnigg D, Lucovnik M, Klieser E, Huber-Katamay J, Moertl MG. Increased cell-free fetal DNA fraction in the first trimester: a sign of abnormally invasive placenta? Ultraschall Med. (2020) 41:5601. doi: $10.1055 / a-0770-5209$

18. Huijsdens-van Amsterdam K, Page-Christiaens L, Flowers N, Bonifacio $\mathrm{MD}$, Ellis $\mathrm{KMB}$, Vogel $\mathrm{I}$, et al. Isochromosome 21q is overrepresented among false-negative cell-free DNA prenatal screening results involving Down syndrome. Eur J Hum Genet. (2018) 26:1490-6. doi: 10.1038/s41431-018-0188-1

19. Pertile MD, Halks-Miller M, Flowers N, Barbacioru C, Kinnings SL, Vavrek $\mathrm{D}$, et al. Rare autosomal trisomies, revealed by maternal plasma DNA sequencing, suggest increased risk of feto-placental disease. Sci Transl Med. (2017) 9:eaan1240. doi: 10.1126/scitranslmed.aan 1240

20. Rafalko JM, Caldwell S, Tynan J, Almasri E, Weinblatt V, McCullough R. Impact of mosaicism ratio on positive predictive value of cfDNA screening. Prenat Diagn. (2021) 41:28-34. doi: 10.1002/pd.5863

21. Palomaki GE, Kloza EM. Prenatal cell-free DNA screening test failures: a systematic review of failure rates, risks of Down syndrome, and impact of repeat testing. Genet Med. (2018) 20:1312-23. doi: 10.1038/gim.2018.22

22. Gregg AR, Skotko BG, Benkendorf JL, Monaghan KG, Bajaj K, Best RG, et al. Noninvasive prenatal screening for fetal aneuploidy, 2016 update: a position statement of the American College of Medical Genetics and Genomics. Genet Med. (2016) 18:1056-65. doi: 10.1038/gim.2016.97

23. Skotko BG, Allyse MA, Bajaj K, Best RG, Klugman S, Leach $\mathrm{M}$, et al. Adherence of cell-free DNA noninvasive prenatal screens to ACMG recommendations. Genet Med. (2019) 21:2285-92. doi: 10.1038/s41436-019-0485-2

24. Miltoft CB, Rode L, Ekelund CK, Sundberg K, Kjaergaard S, Zingenberg $\mathrm{H}$, et al. Contingent first-trimester screening for aneuploidies with cellfree DNA in a Danish clinical setting. Ultrasound Obstet Gynecol. (2018) 51:470-9. doi: 10.1002/uog.17562

25. Revello R, Sarno L, Ispas A, Akolekar R, Nicolaides KH. Screening for trisomies by cell-free DNA testing of maternal blood: consequences of a failed result. Ultrasound Obstet Gynecol. (2016) 47:698-704. doi: 10.1002/uog.15851

26. Hestand MS, Bessem M, van Rijn P, de Menezes RX, Sie D, Bakker $\mathrm{I}$, et al. Fetal fraction evaluation in non-invasive prenatal screening (NIPS). Eur J Hum Genet. (2019) 27:198-202. doi: 10.1038/s41431-0180271-7

27. Suzumori N, Ebara T, Yamada T, Samura O, Yotsumoto J, Nishiyama M, et al. Fetal cell-free DNA fraction in maternal plasma is affected by fetal trisomy. $J$ Hum Genet. (2016) 61:647-52. doi: 10.1038/jhg.2016.25

28. Qiao L, Yu B, Liang Y, Zhang C, Wu X, Xue Y, et al. Sequencing shorter cfDNA fragments improves the fetal DNA fraction in noninvasive prenatal testing. Am J Obstet Gynecol. (2019) 221:345.e341-5.e311. doi: 10.1016/j.ajog.2019.05.023

29. Talbot AL, Ambye L, Hartwig TS, Werge L, Sørensen S, Stormlund S, et al. Fetal fraction of cell-free DNA in pregnancies after fresh or frozen embryo transfer following assisted reproductive technologies. Hum Reprod. (2020) 35:1267-75. doi: 10.1093/humrep/deaa110

30. Guo FF, Yang JX, Huang YL, Qi YM, Hou YP, Peng HS, et al. Association between fetal fraction at the second trimester and subsequent spontaneous preterm birth. Prenat Diagn. (2019) 39:1191-7. doi: 10.1002/pd.5566

31. Lambert-Messerlian G, Kloza EM, Williams J 3rd, Loucky J, O’Brien B, Wilkins-Haug L, et al. Maternal plasma DNA testing for aneuploidy in pregnancies achieved by assisted reproductive technologies. Genet Med. (2014) 16:419-22. doi: 10.1038/gim.2013.149

32. Hou Y, Yang J, Qi Y, Guo F, Peng H, Wang D, et al. Factors affecting cell-free DNA fetal fraction: statistical analysis of 13,661 maternal plasmas for non-invasive prenatal screening. Hum Genomics. (2019) 13:62. doi: 10.1186/s40246-019-0244-0

33. Brar H, Wang E, Struble C, Musci TJ, Norton ME. The fetal fraction of cell-free DNA in maternal plasma is not affected by a priori risk of fetal trisomy. J Matern Fetal Neonatal Med. (2013) 26:1435. doi: 10.3109/14767058.2012.722731

34. Hudecova I, Sahota D, Heung MM, Jin Y, Lee WS, Leung TY, et al. Maternal plasma fetal DNA fractions in pregnancies with low and high risks for fetal chromosomal aneuploidies. PLoS ONE. (2014) 9:e88484. doi: 10.1371/journal.pone.0088484

35. Krishna I, Badell M, Loucks TL, Lindsay M, Samuel A. Adverse perinatal outcomes are more frequent in pregnancies with a low fetal fraction result on noninvasive prenatal testing. Prenat Diagn. (2016) 36:2105. doi: 10.1002/pd.4779

36. Miltoft CB, Rode L, Bundgaard JR, Johansen P, Tabor A. Cell-free fetal DNA in the early and late first trimester. Fetal Diagn Ther. (2020) 47:22836. doi: 10.1159/000502179

37. Ashoor G, Poon L, Syngelaki A, Mosimann B, Nicolaides KH. Fetal fraction in maternal plasma cell-free DNA at 11-13 weeks' gestation: effect of maternal and fetal factors. Fetal Diagn Ther. (2012) 31:23743. doi: $10.1159 / 000337373$

38. Lee TJ, Rolnik DL, Menezes MA, McLennan AC, da Silva Costa F. Cellfree fetal DNA testing in singleton IVF conceptions. Hum Reprod. (2018) 33:572-8. doi: 10.1093/humrep/dey033

39. Dabi Y, Guterman S, Jani JC, Letourneau A, Demain A, Kleinfinger $\mathrm{P}$, et al. Autoimmune disorders but not heparin are associated with cell-free fetal DNA test failure. J Transl Med. (2018) 16:335. doi: 10.1186/s12967-018-1705-2

40. Burns W, Koelper N, Barberio A, Deagostino-Kelly M, Mennuti M, Sammel $\mathrm{MD}$, et al. The association between anticoagulation therapy, maternal characteristics, and a failed cfDNA test due to a low fetal fraction. Prenat Diagn. (2017) 37:1125-9. doi: 10.1002/pd.5152

41. Zhou Y, Zhu Z, Gao Y, Yuan Y, Guo Y, Zhou L, et al. Effects of maternal and fetal characteristics on cell-free fetal DNA fraction in maternal plasma. Reprod Sci. (2015) 22:1429-35. doi: 10.1177/1933719115584445

42. Kuhlmann-Capek M, Chiossi G, Singh P, Monsivais L, Lozovyy V, Gallagher $\mathrm{L}$, et al. Effects of medication intake in early pregnancy on the fetal fraction of cell-free DNA testing. Prenat Diagn. (2019) 39:361-8. doi: 10.1002/pd.5436

43. Schlütter JM, Hatt L, Bach C, Kirkegaard I, Kølvraa S, Uldbjerg N. The cellfree fetal DNA fraction in maternal blood decreases after physical activity. Prenat Diagn. (2014) 34:341-4. doi: 10.1002/pd.4306

44. Hopkins MK, Koelper N, Bender W, Durnwald C, Sammel M, Dugoff L. Association between cell-free DNA fetal fraction and gestational diabetes. Prenat Diagn. (2020) 40:724-7. doi: 10.1002/pd.5671

45. Putra M, Idler J, Patek K, Contos G, Walker C, Olson D, et al. The association of HBB-related significant hemoglobinopathies and low fetal fraction on noninvasive prenatal screening for fetal aneuploidy. J Matern Fetal Neonatal Med. (2021) 34:3657-61. doi: 10.1080/14767058.2019.1689558

46. Kinnings SL, Geis JA, Almasri E, Wang H, Guan X, McCullough RM, et al. Factors affecting levels of circulating cell-free fetal DNA in maternal plasma and their implications for noninvasive prenatal testing. Prenat Diagn. (2015) 35:816-22. doi: 10.1002/pd.4625

47. Rolnik DL, da Silva Costa F, Lee TJ, Schmid M, McLennan AC. Association between fetal fraction on cell-free DNA testing and firsttrimester markers for pre-eclampsia. Ultrasound Obstet Gynecol. (2018) 52:722-7. doi: 10.1002/uog.18993

48. Vora NL, Johnson KL, Basu S, Catalano PM, Hauguel-De Mouzon S, Bianchi DW. A multifactorial relationship exists between total circulating cell-free DNA levels and maternal BMI. Prenat Diagn. (2012) 32:9124. doi: 10.1002/pd.3919

49. Canick JA, Palomaki GE, Kloza EM, Lambert-Messerlian GM, Haddow JE. The impact of maternal plasma DNA fetal fraction on next generation sequencing tests for common fetal aneuploidies. Prenat Diagn. (2013) 33:667-74. doi: 10.1002/pd.4126

50. Bose P, Black S, Kadyrov M, Weissenborn U, Neulen J, Regan L, et al. Heparin and aspirin attenuate placental apoptosis in vitro: implications for early pregnancy failure. Am J Obstet Gynecol. (2005) 192:2330. doi: 10.1016/j.ajog.2004.09.029

51. Tersigni C, Marana R, Santamarìa A, Castellani R, Scambia G, Simone ND. In vitro evidences of heparin's effects on embryo implantation and trophoblast development. Reprod Sci. (2012) 19:454-62. doi: 10.1177/1933719111430994 
52. Chan RW, Jiang P, Peng X, Tam LS, Liao GJ, Li EK, et al. Plasma DNA aberrations in systemic lupus erythematosus revealed by genomic and methylomic sequencing. Proc Natl Acad Sci USA. (2014) 111:E530211. doi: 10.1073/pnas.1421126111

53. Schuring-Blom H, Lichtenbelt $K$, van Galen K, Elferink M, Weiss $M$, Vermeesch JR, et al. Maternal vitamin B12 deficiency and abnormal cell-free DNA results in pregnancy. Prenat Diagn. (2016) 36:7903. doi: $10.1002 / \mathrm{pd} .4863$

54. Hui L, Bethune M, Weeks A, Kelley J, Hayes L. Repeated failed non-invasive prenatal testing owing to low cell-free fetal DNA fraction and increased variance in a woman with severe autoimmune disease. Ultrasound Obstet Gynecol. (2014) 44:242-3. doi: 10.1002/uog.13418

55. Chan N, Smet ME, Sandow R, da Silva Costa F, McLennan A. Implications of failure to achieve a result from prenatal maternal serum cellfree DNA testing: a historical cohort study. BJOG. (2018) 125:84855. doi: 10.1111/1471-0528.15006

56. Manokhina I, Singh TK, Robinson WP. Cell-free placental DNA in maternal plasma in relation to placental health and function. Fetal Diagn Ther. (2017) 41:258-64. doi: 10.1159/000448707

57. Poon LC, Musci T, Song K, Syngelaki A, Nicolaides KH. Maternal plasma cell-free fetal and maternal DNA at 11-13 weeks' gestation: relation to fetal and maternal characteristics and pregnancy outcomes. Fetal Diagn Ther. (2013) 33:215-23. doi: 10.1159/000346806

58. Chen M, Jiang F, Guo Y, Yan H, Wang J, Zhang L, et al. Validation of fetal DNA fraction estimation and its application in noninvasive prenatal testing for aneuploidy detection in multiple pregnancies. Prenat Diagn. (2019) 39:1273-82. doi: 10.1002/pd.5597

59. Bevilacqua E, Gil MM, Nicolaides KH, Ordoñez E, Cirigliano V, Dierickx H, et al. Performance of screening for aneuploidies by cell-free DNA analysis of maternal blood in twin pregnancies. Ultrasound Obstet Gynecol. (2015) 45:61-6. doi: 10.1002/uog.14690

60. Sarno L, Revello R, Hanson E, Akolekar R, Nicolaides KH. Prospective first-trimester screening for trisomies by cell-free DNA testing of maternal blood in twin pregnancy. Ultrasound Obstet Gynecol. (2016) 47:70511. doi: 10.1002/uog.15913

61. Lopes JL, Lopes GS, Enninga EAL, Kearney HM, Hoppman NL, Rowsey RA. Most noninvasive prenatal screens failing due to inadequate fetal cell free DNA are negative for trisomy when repeated. Prenat Diagn. (2020) 40:831-7. doi: $10.1002 /$ pd.5693

62. Bender WR, Koelper NC, Sammel MD, Dugoff L. Association of fetal fraction of cell-free DNA and hypertensive disorders of pregnancy. Am J Perinatol. (2019) 36:311-6. doi: 10.1055/s-0038-1667374

63. Gerson KD, Truong S, Haviland MJ, O’Brien BM, Hacker MR, Spiel MH. Low fetal fraction of cell-free DNA predicts placental dysfunction and hypertensive disease in pregnancy. Pregnancy Hypertens. (2019) 16:14853. doi: 10.1016/j.preghy.2019.04.002

64. Hedriana H, Martin K, Saltzman D, Billings P, Demko Z, Benn P. Cell-free DNA fetal fraction in twin gestations in single-nucleotide polymorphismbased noninvasive prenatal screening. Prenat Diagn. (2020) 40:17984. doi: 10.1002/pd.5609

65. Canick JA, Kloza EM, Lambert-Messerlian GM, Haddow JE, Ehrich M, van den Boom D, et al. DNA sequencing of maternal plasma to identify Down syndrome and other trisomies in multiple gestations. Prenat Diagn. (2012) 32:730-4. doi: 10.1002/pd.3892

66. Fosler L, Winters P, Jones KW, Curnow KJ, Sehnert AJ, Bhatt S, et al. Aneuploidy screening by non-invasive prenatal testing in twin pregnancy. Ultrasound Obstet Gynecol. (2017) 49:470-7. doi: 10.1002/uog.15964

67. Yuan X, Zhou L, Zhang B, Wang H, Yu B, Xu J. Association between low fetal fraction of cell free DNA at the early second-trimester and adverse pregnancy outcomes. Pregnancy Hypertens. (2020) 22:1018. doi: 10.1016/j.preghy.2020.07.015

68. Carrara J, Vivanti A, Jani JC, Demain A, Costa JM, Benachi A. Usefulness and reliability of cell free fetal DNA screening for main trisomies in case of atypical profile on first trimester maternal serum screening. J Transl Med. (2019) 17:398. doi: 10.1186/s12967-019-02152-7

69. Morano D, Rossi S, Lapucci C, Pittalis MC, Farina A. Cell-free DNA (cfDNA) fetal fraction in early- and late-onset fetal growth restriction. Mol Diagn Ther. (2018) 22:613-9. doi: 10.1007/s40291-018-0353-9
70. Samuel A, Bonanno C, Oliphant A, Batey A, Wright JD. Fraction of cellfree fetal DNA in the maternal serum as a predictor of abnormal placental invasion-a pilot study. Prenat Diagn. (2013) 33:1050-3. doi: 10.1002/pd.4195

71. Clapp MA, Berry M, Shook LL, Roberts PS, Goldfarb IT, Bernstein $\mathrm{SN}$. Low fetal fraction and birth weight in women with negative first-trimester cell-free DNA screening. Am J Perinatol. (2020) 37:8691. doi: 10.1055/s-0039-1700860

72. Qiao L, Zhang Q, Liang Y, Gao A, Ding Y, Zhao N, et al. Sequencing of short cfDNA fragments in NIPT improves fetal fraction with higher maternal BMI and early gestational age. Am J Transl Res. (2019) 11:4450-9.

73. Song Y, Zhou X, Huang S, Li X, Qi Q, Jiang Y, et al. Quantitation of fetal DNA fraction in maternal plasma using circulating single molecule amplification and re-sequencing technology (cSMART). Clin Chim Acta. (2016) 456:151-6. doi: 10.1016/j.cca.2016.03.005

74. Bai Z, Zhao H, Lin S, Huang L, He Z, Wang H, et al. Evaluation of a microhaplotype-based noninvasive prenatal test in twin gestations: determination of paternity, zygosity, and fetal fraction. Genes. (2020) 12:26. doi: 10.3390/genes 12010026

75. Khalil A, Archer R, Hutchinson V, Mousa HA, Johnstone ED, Cameron $\mathrm{MJ}$, et al. Non-invasive prenatal screening in twin pregnancies with cellfree DNA using the IONA test: a prospective multicentre study. Am J Obstet Gynecol. (2021) 225:79.e1-79. doi: 10.1016/j.ajog.2021.01.005

76. Le Conte G, Letourneau A, Jani J, Kleinfinger P, Lohmann L, Costa JM, et al. Cell-free fetal DNA analysis in maternal plasma as screening test for trisomies 21, 18 and 13 in twin pregnancy. Ultrasound Obstet Gynecol. (2018) 52:318-24. doi: 10.1002/uog.18838

77. Leung TY, Qu JZ, Liao GJ, Jiang P, Cheng YK, Chan KC, et al. Noninvasive twin zygosity assessment and aneuploidy detection by maternal plasma DNA sequencing. Prenat Diagn. (2013) 33:675-81. doi: 10.1002/pd.4132

78. Qu JZ, Leung TY, Jiang P, Liao GJ, Cheng YK, Sun H, et al. Noninvasive prenatal determination of twin zygosity by maternal plasma DNA analysis. Clin Chem. (2013) 59:427-35. doi: 10.1373/clinchem.2012.194068

79. Zou Y, Cui L, Xue M, Yan J, Huang M, Gao M, et al. Applications of noninvasive prenatal testing in vanishing twin syndrome pregnancies after treatment of assisted reproductive technology in a single center. Prenat Diagn. (2021) 41:226-33. doi: 10.1002/pd.5836

80. Hartwig TS, Ambye L, Werge L, Weiergang MK, Nørgaard P, Sørensen S, et al. Non-Invasive Prenatal Testing (NIPT) in pregnancies with trisomy 21, 18 and 13 performed in a public setting - factors of importance for correct interpretation of results. Eur J Obstet Gynecol Reprod Biol. (2018) 226:35-9. doi: 10.1016/j.ejogrb.2018.04.042

81. Balaguer N, Mateu-Brull E, Serra V, Simón C, Milán M. Should vanishing twin pregnancies be systematically excluded from cell-free fetal DNA testing? Prenat Diagn. (2020) 41:1222-32. doi: 10.1002/pd.5817

82. Wong D, Moturi S, Angkachatchai V, Mueller R, DeSantis G, van den Boom $\mathrm{D}$, et al. Optimizing blood collection, transport and storage conditions for cell free DNA increases access to prenatal testing. Clin Biochem. (2013) 46:1099-104. doi: 10.1016/j.clinbiochem.2013.04.023

83. Clausen FB, Barrett AN, Advani HV, Choolani M, Dziegiel MH. Impact of long-term storage of plasma and cell-free DNA on measured DNA quantity and fetal fraction. Vox Sang. (2020) 115:586-94. doi: 10.1111/vox.12923

84. Xie X, Li F, Tan W, Yin W, Chen F, Guo X. The effect of freezing on non-invasive prenatal testing. Sci Rep. (2019) 9:6962. doi: 10.1038/s41598-019-42980-7

85. Fernando MR, Jiang C, Krzyzanowski GD, Somer-Shely T, Ryan WL. A novel approach to stabilize fetal cell-free DNA fraction in maternal blood samples for extended period of time. PLOS ONE. (2018) 13:e0208508. doi: 10.1371/journal.pone.0208508

86. Hidestrand M, Stokowski R, Song K, Oliphant A, Deavers J, Goetsch M, et al. Influence of temperature during transportation on cell-free DNA analysis. Fetal Diagn Ther. (2012) 31:122-8. doi: 10.1159/000335020

87. Medina Diaz I, Nocon A, Mehnert DH, Fredebohm J, Diehl F, Holtrup F. Performance of streck cfDNA blood collection tubes for liquid biopsy testing. PLoS ONE. (2016) 11:e0166354. doi: 10.1371/journal.pone.0166354

88. Sillence KA, Roberts LA, Hollands HJ, Thompson HP, Kiernan M, Madgett TE, et al. Fetal sex and RHD genotyping with digital PCR demonstrates greater sensitivity than real-time PCR. Clin Chem. (2015) 61:1399-407. doi: 10.1373/clinchem.2015.239137 
89. Stokowski R, White K, Hacker C, Doshi J, Schmid M. Hemolysis and fetal fraction in cell-free DNA blood collection tubes for noninvasive prenatal testing. Mol Diagn Ther. (2020) 24:185-90. doi: 10.1007/s40291-020-00446-x

90. Qiao L, Mao J, Liu M, Liu Y, Song X, Tang H, et al. Experimental factors are associated with fetal fraction in size selection noninvasive prenatal testing. Am J Transl Res. (2019) 11:6370-81.

91. Balslev-Harder M, Richter SR, Kjaergaard S, Johansen P. Correlation between $\mathrm{Z}$ score, fetal fraction, and sequencing reads in non-invasive prenatal testing. Prenat Diagn. (2017) 37:943-5. doi: 10.1002/pd.5116

92. Xu XP, Gan HY, Li FX, Tian Q, Zhang J, Liang RL, et al. A method to quantify cell-free fetal DNA fraction in maternal plasma using next generation sequencing: its application in non-invasive prenatal chromosomal aneuploidy detection. PLoS ONE. (2016) 11:e0146997. doi: 10.1371/journal.pone.0146997

93. Peng XL, Jiang P. Bioinformatics approaches for fetal DNA fraction estimation in noninvasive prenatal testing. Int J Mol Sci. (2017) 18:453. doi: 10.3390/ijms18020453

94. Hui L, Bianchi DW. Fetal fraction and noninvasive prenatal testing: what clinicians need to know. Prenat Diagn. (2020) 40:155-63. doi: 10.1002/pd.5620

95. van Beek DM, Straver R, Weiss MM, Boon EMJ, Huijsdens-van Amsterdam $\mathrm{K}$, Oudejans CBM, et al. Comparing methods for fetal fraction determination and quality control of NIPT samples. Prenat Diagn. (2017) 37:76973. doi: 10.1002/pd.5079

96. El Khattabi LA, Brun S, Gueguen P, Chatron N, Guichoux E, Schutz S, et al. Performance of semiconductor sequencing platform for non-invasive prenatal genetic screening for fetal aneuploidy: results from a multicenter prospective cohort study in a clinical setting. Ultrasound Obstet Gynecol. (2019) 54:246-54. doi: 10.1002/uog.20112

97. Raman L, Baetens M, De Smet M, Dheedene A, Van Dorpe J, Menten B. PREFACE: In silico pipeline for accurate cell-free fetal DNA fraction prediction. Prenat Diagn. (2019) 39:925-33. doi: 10.1002/pd.5508

98. Bayindir B, Dehaspe L, Brison N, Brady P, Ardui S, Kammoun M, et al. Noninvasive prenatal testing using a novel analysis pipeline to screen for all autosomal fetal aneuploidies improves pregnancy management. Eur J Hum Genet. (2015) 23:1286-93. doi: 10.1038/ejhg.2014.282

99. Sparks AB, Struble CA, Wang ET, Song K, Oliphant A. Noninvasive prenatal detection and selective analysis of cell-free DNA obtained from maternal blood: evaluation for trisomy 21 and trisomy 18. Am J Obstet Gynecol. (2012) 206:319.e311-9. doi: 10.1016/j.ajog.2012.01.030

100. Schmid M, White K, Stokowski R, Miller D, Bogard PE, Valmeekam V, et al. Accuracy and reproducibility of fetal-fraction measurement using relative quantitation at polymorphic loci with microarray. Ultrasound Obstet Gynecol. (2018) 51:813-7. doi: 10.1002/uog.19036

101. Galeva S, Gil MM, Konstantinidou L, Akolekar R, Nicolaides KH. Firsttrimester screening for trisomies by cfDNA testing of maternal blood in singleton and twin pregnancies: factors affecting test failure. Ultrasound Obstet Gynecol. (2019) 53:804-9. doi: 10.1002/uog.20290

102. Ryan A, Hunkapiller N, Banjevic M, Vankayalapati N, Fong N, Jinnett $\mathrm{KN}$, et al. Validation of an enhanced version of a single-nucleotide polymorphism-based noninvasive prenatal test for detection of fetal aneuploidies. Fetal Diagn Ther. (2016) 40:219-23. doi: 10.1159/000442931

103. Norwitz ER, McNeill G, Kalyan A, Rivers E, Ahmed E, Meng L, et al. Validation of a single-nucleotide polymorphism-based non-invasive prenatal test in twin gestations: determination of zygosity, individual fetal sex, and fetal aneuploidy. J Clin Med. (2019) 8:937. doi: 10.3390/jcm8070937

104. Barrett AN, Xiong L, Tan TZ, Advani HV, Hua R, Laureano-Asibal C, et al. Measurement of fetal fraction in cell-free DNA from maternal plasma using a panel of insertion/deletion polymorphisms. PLOS ONE. (2017) 12:e0186771. doi: 10.1371/journal.pone.0186771

105. Grendár M, Loderer D, Laučeková Z, Švecová I, Hrtánková M, Hornáková A, et al. Uncertainty of fetal fraction determination in non-invasive prenatal screening by highly polymorphic SNPs. J Biotechnol. (2019) 299:326. doi: 10.1016/j.jbiotec.2019.04.020

106. Larson NB, Wang C, Na J, Rowsey RA, Highsmith WE, Hoppman NL, et al. Improving single-nucleotide polymorphism-based fetal fraction estimation of maternal plasma circulating cell-free DNA using Bayesian Hierarchical Models. J Comput Biol. (2018) 25:1040-9. doi: 10.1089/cmb.2018.0056
107. Kim SK, Hannum G, Geis J, Tynan J, Hogg G, Zhao C, et al. Determination of fetal DNA fraction from the plasma of pregnant women using sequence read counts. Prenat Diagn. (2015) 35:810-5. doi: 10.1002/pd.4615

108. Manokhina I, Singh TK, Penaherrera MS, Robinson WP. Quantification of cell-free DNA in normal and complicated pregnancies: overcoming biological and technical issues. PLoS ONE. (2014) 9:e101500. doi: 10.1371/journal.pone.0101500

109. Nygren AO, Dean J, Jensen TJ, Kruse S, Kwong W, van den Boom D, et al. Quantification of fetal DNA by use of methylation-based DNA discrimination. Clin Chem. (2010) 56:1627-35. doi: 10.1373/clinchem.2010.146290

110. Jensen TJ, Kim SK, Zhu Z, Chin C, Gebhard C, Lu T, et al. Whole genome bisulfite sequencing of cell-free DNA and its cellular contributors uncovers placenta hypomethylated domains. Genome Biol. (2015) 16:78. doi: 10.1186/s13059-015-0645-x

111. Yu SC, Chan KC, Zheng YW, Jiang P, Liao GJ, Sun H, et al. Sizebased molecular diagnostics using plasma DNA for noninvasive prenatal testing. Proc Natl Acad Sci USA. (2014) 111:8583-8. doi: 10.1073/pnas.14061 03111

112. Fan HC, Blumenfeld YJ, Chitkara U, Hudgins L, Quake SR Analysis of the size distributions of fetal and maternal cellfree DNA by paired-end sequencing. Clin Chem. (2010) 56:1279-86. doi: 10.1373/clinchem.2010.144188

113. Straver R, Oudejans CB, Sistermans EA, Reinders MJ. Calculating the fetal fraction for noninvasive prenatal testing based on genome-wide nucleosome profiles. Prenat Diagn. (2016) 36:614-21. doi: 10.1002/pd.4816

114. Lo YM, Chan KC, Sun H, Chen EZ, Jiang P, Lun FM, et al. Maternal plasma DNA sequencing reveals the genome-wide genetic and mutational profile of the fetus. Sci Transl Med. (2010) 2:61 ra91. doi: 10.1126/scitranslmed.3001720

115. Liao GJ, Lun FM, Zheng YW, Chan KC, Leung TY, Lau TK, et al. Targeted massively parallel sequencing of maternal plasma DNA permits efficient and unbiased detection of fetal alleles. Clin Chem. (2011) 57:92101. doi: $10.1373 /$ clinchem. 2010.154336

116. Jiang P, Chan KC, Liao GJ, Zheng YW, Leung TY, Chiu RW, et al. FetalQuant: deducing fractional fetal DNA concentration from massively parallel sequencing of DNA in maternal plasma. Bioinformatics. (2012) 28:2883-90. doi: 10.1093/bioinformatics/bts549

117. Jiang P, Peng X, Su X, Sun K, Yu SCY, Chu WI, et al. FetalQuant(SD): accurate quantification of fetal DNA fraction by shallow-depth sequencing of maternal plasma DNA. NPJ Genom Med. (2016) 1:16013. doi: $10.1038 /$ npjgenmed.2016.13

118. Yuan Y, Chai X, Liu N, Gu B, Li S, Gao Y, et al. FF-QuantSC: accurate quantification of fetal fraction by a neural network model. Mol Genet Genomic Med. (2020) 8:e1232. doi: 10.1002/mgg3.1232

119. Friedman J, Hastie T, Tibshirani R. Regularization paths for generalized linear models via coordinate descent. J Stat Softw. (2010) 33:1-22. doi: 10.18637/jss.v033.i01

120. Izenman A. Reduced-rank regression for the multivariate linear model. $J$ Multivar Anal. (1975) 5:248-64. doi: 10.1016/0047-259X(75)90042-1

121. Zeng Y, Gao J, Yuan H, Zhou L, Cheng D, Che M, et al. Application of FF-QuantSC for the precise estimation of fetal fraction in noninvasive prenatal testing in two SRY-translocation cases. Front Genet. (2020) 11:570333. doi: 10.3389/fgene.2020.570333

122. Wataganara T, Bui TH, Choy KW, Leung TY. Debates on fetal fraction measurement and DNA-based noninvasive prenatal screening: time for standardisation? BJOG. (2016) 123(Suppl 3):31-5. doi: 10.1111/1471-0528.14197

123. Deans ZC, Allen S, Jenkins L, Khawaja F, Hastings RJ, Mann K, et al. Recommended practice for laboratory reporting of non-invasive prenatal testing of trisomies 13, 18 and 21: a consensus opinion. Prenat Diagn. (2017) 37:699-704. doi: 10.1002/pd.5068

124. Kim M, Kim JH, Kim K, Kim S. Cost-effective and accurate method of measuring fetal fraction using SNP imputation. Bioinformatics. (2018) 34:1086-91. doi: 10.1093/bioinformatics/btx728

125. Gazdarica J, Hekel R, Budis J, Kucharik M, Duris F, Radvanszky J, et al. Combination of fetal fraction estimators based on fragment lengths and fragment counts in non-invasive prenatal testing. Int J Mol Sci. (2019) 20:3959. doi: 10.3390/ijms20163959 
126. Dang $\mathrm{M}, \mathrm{Xu} \mathrm{H}$, Zhang J, Wang W, Bai L, Fang N, et al. Inferring fetal fractions from read heterozygosity empowers the noninvasive prenatal screening. Genet Med. (2020) 22:301-8. doi: 10.1038/s41436-019-0636-5

127. Welker NC, Lee AK, Kjolby RAS, Wan HY, Theilmann MR, Jeon D, et al. High-throughput fetal fraction amplification increases analytical performance of noninvasive prenatal screening. Genet Med. (2021) 23:44350. doi: 10.1101/2020.07.12.20034926

128. Xue Y, Zhao G, Qiao L, Lu J, Yu B, Wang T. Sequencing shorter cfDNA fragments decreases the false negative rate of non-invasive prenatal testing. Front Genet. (2020) 11:280. doi: 10.3389/fgene.2020. 00280

129. Benn P, Valenti E, Shah S, Martin K, Demko Z. Factors associated with informative redraw after an initial no result in noninvasive prenatal testing. Obstet Gynecol. (2018) 132:428-35. doi: 10.1097/AOG.0000000000 002728

130. Tongsong T, Sirichotiyakul S, Wanapirak C, Chanprapaph P. Sonographic features of trisomy 18 at midpregnancy. J Obstet Gynaecol Res. (2002) 28:245-50. doi: 10.1046/j.1341-8076.2002.00053.x

131. Watson WJ, Miller RC, Wax JR, Hansen WF, Yamamura Y, Polzin WJ. Sonographic detection of trisomy 13 in the first and second trimesters of pregnancy. J Ultrasound Med. (2007) 26:1209-14. doi: 10.7863/jum.2007.26.9.1209

Conflict of Interest: The authors declare that the research was conducted in the absence of any commercial or financial relationships that could be construed as a potential conflict of interest.

Publisher's Note: All claims expressed in this article are solely those of the authors and do not necessarily represent those of their affiliated organizations, or those of the publisher, the editors and the reviewers. Any product that may be evaluated in this article, or claim that may be made by its manufacturer, is not guaranteed or endorsed by the publisher.

Copyright (๑) 2022 Deng and Liu. This is an open-access article distributed under the terms of the Creative Commons Attribution License (CC BY). The use, distribution or reproduction in other forums is permitted, provided the original author(s) and the copyright owner(s) are credited and that the original publication in this journal is cited, in accordance with accepted academic practice. No use, distribution or reproduction is permitted which does not comply with these terms. 